\section{Deterioration of Soil-biodegradable Mulch Films during Storage and Its Impact on Specialty Crop Production}

\author{
Marife B. Anunciado ${ }^{1}$, Larry C. Wadsworth ${ }^{1}$, Shuresh Ghimire ${ }^{2}$, \\ Carol Miles ${ }^{3}$, Jenny C. Moore ${ }^{4}$, Annette L. Wszelaki ${ }^{4}$, and \\ Douglas G. Hayes ${ }^{1}$
}

ADDITIONAL INDEX WORDs. aging of plastics, long-term storage, plasticulture, polybutylene adipate terephthalate, polylactic acid, vegetables

SumMary. Plastic mulch films contribute to improved crop yield and quality for vegetable and small fruit cropping systems. Although the single-season agronomic performance of conventional polyethylene mulches and soilbiodegradable mulches (BDMs) are similar, over time BDMs can begin to break down during storage and subsequently not provide season-long soil coverage. In this study, the changes in physicochemical properties of BDMs were investigated over 3 years of indoor storage (2015-18) under ideal environmental conditions in two laboratories. Mulches evaluated were black, 20-40 $\mu \mathrm{m}$ thick, suitable for annual vegetable production, and included three BDMs: two polybutylene adipate terephthalate (PBAT)-enriched mulches that are commercially available in North America, an experimental polylactic acid (PLA) and polyhydroxyalkanote-based film, and a conventional polyethylene mulch as a control. Tensile properties, specifically peak load and elongation at maximum tensile stress, decreased during storage, particularly for the PBATbased BDMs, indicating a loss of strength. During year 3 of storage, the tensile properties declined extensively, suggesting embrittlement. The average molecular weight of PLA and PBAT slightly increased during year 1, perhaps due to release of monomers or oligomers, and then decreased extensively during years 2 and 3 due to hydrolysis of ester bonds (confirmed by Fourier transform infrared spectroscopic analysis). The structural integrity of BDMs was assessed during years 2 and 3 of the study (2017-18) in field trials at the locations where they were stored, Knoxville, TN, and Mount Vernon, WA, for vegetable production. The degradation of the BDMs during the cropping season was higher in 2018 compared with 2017, suggesting that degradation of mechanical and chemical properties while in storage may have contributed to rapid degradation of mulches in the field. In summary, BDMs undergo degradation even under ideal storage conditions and may perform best if deployed within 2 years of their receipt date. The farmer should verify that proper storage conditions have been used before receipt and that manufacturing date precedes the receipt date by no more than 6 months.

$\mathrm{P}$ astic mulch films are employed for agricultural production of vegetables and other specialty crops due to the numerous benefits they provide. The benefits include, but are not limited to, reduction of weeds and diseases, modulation of soil temperature, and reduction of soil erosion and evaporative loss of soil moisture, all of which lead to improved productivity and quality of the crops (Guerrini et al., 2019; Kasirajan and Ngouajio, 2012). However, the increasing use of conventional polyethylene (PE) mulches contributes to the serious issue of worldwide plastic pollution, which threatens environmental sustainability and soil health (Hayes et al., 2019; SerranoRuiz et al., 2021).

BDMs serve as a sustainable alternative to conventional $\mathrm{PE}$ mulches (DeVetter et al., 2017; Ghimire et al., 2018; Lalitha et al., 2010; Miles et al., 2017; Moore and Wszelaki, 2019; Zhang et al., 2019). BDMs are tilled into the soil after crop harvest, where they biodegrade into carbon dioxide $\left(\mathrm{CO}_{2}\right)$, water, and microbial biomass. The replacement of $\mathrm{PE}$ mulches with BDMs promotes more sustainable cultivation through reduction of plastic contamination of soil and plastic environmental pollution (Hayes et al., 2019; Scarascia-Mugnozza et al., 2006; Serrano-Ruiz et al., 2021).

It is critically important that mulch films deployed for specialty crop production possess high mechanical strength and durability to withstand elongation and rupture when subjected to machine laying (Nogueira and Martins, 2019) as well as chemical degradation due to sunlight and other environmental factors (Anunciado et al., 2021; Kijchavengkul and Auras, 2008; Moreno et al., 2017). Degradation of plastics is a long-term process driven by several factors, such as ultraviolet radiation, temperature stress, mechanical action, and loss of additives that are slowly released from the mulches over time, such as colorants, plasticizers, monomers, and oligomers (Emadian et al., 2017; Kasirajan and Ngouajio, 2012; Krueger et al., 2015; Serrano Ruiz et al., 2020; Sintim et al., 2019). Proper storage of mulches before use is important to minimize degradation and to ensure satisfactory performance in the field. BDM manufacturers

\begin{tabular}{llll}
\hline $\begin{array}{l}\text { Units } \\
\begin{array}{l}\text { To convert U.S. to SI, } \\
\text { multiply by }\end{array}\end{array}$ & U.S. unit & SI unit & $\begin{array}{l}\text { To convert SI to } \\
\text { U.S., } \\
\text { multiply by }\end{array}$ \\
\hline 29,574 & $\mathrm{fl} \mathrm{oz}$ & $\mu \mathrm{L}$ & $3.3814 \times 10^{-5}$ \\
29.5735 & $\mathrm{fl} \mathrm{oz}$ & $\mathrm{mL}$ & 0.0338 \\
0.3048 & $\mathrm{ft}$ & $\mathrm{m}$ & 3.2808 \\
3.7854 & $\mathrm{gal}$ & $\mathrm{L}$ & 0.2642 \\
2.54 & inch $(\mathrm{es})$ & $\mathrm{cm}$ & 0.3937 \\
25.4 & inch(es) & $\mathrm{mm}$ & 0.0394 \\
1.1209 & $\mathrm{lb} / \mathrm{acre}$ & $\mathrm{kg} \cdot \mathrm{ha}{ }^{-1}$ & 0.8922 \\
4.4482 & $\mathrm{lbf}$ & $\mathrm{N}$ & 0.2248 \\
1 & $\mathrm{micron}(\mathrm{s})$ & $\mu \mathrm{m}$ & 1 \\
25.4 & $\mathrm{mil}(\mathrm{s})$ & $\mu \mathrm{m}$ & 0.0394 \\
28,350 & $\mathrm{Oz}$ & $\mathrm{mg}$ & $3.5274 \times 10^{-5}$ \\
$\left({ }^{\circ} \mathrm{F}-32\right) \div 1.8$ & ${ }^{\circ} \mathrm{F}$ & ${ }^{\circ} \mathrm{C}$ & $\left({ }^{\circ} \mathrm{C} \times 1.8\right)+32$ \\
\hline
\end{tabular}


recommend that growers store mulches in a cool and dry location, without direct contact with water, heating sources, or small rodents, and wrap them in black film to protect from sunlight and to minimize the occurrence of accidental cracks or punctures (DuBois Agroinovation, 2021).

Aging of plastics can be categorized into chemical aging due to chemical reactions (e.g., oxidation) that contribute to decreases in molecular weight or physical aging that is manifested through changes in thermal, mechanical (e.g., fracture and embrittlement), and/or electrical properties of the material (Harvey, 2005; Ming and Chen, 2020; Moreno et al., 2017; Yin et al., 2019). Both mechanisms of aging can be influenced by environmental factors. For example, Mosnáčková et al. (2019) found that the mechanical properties of a BDM composed of a blend of PLA and polyhydroxyalkanoate (PHA) became greatly embrittled due to environmental weathering during a

Received for publication 28 July 2021. Accepted for publication 24 Sept. 2021.

Published online 16 November 2021

${ }^{1}$ Department of Biosystems Engineering and Soil Science, University of Tennessee, Knoxville, TN 37996

${ }^{2}$ Department of Extension, University of Connecticut, Vernon, CT 06066

${ }^{3}$ Department of Horticulture, Washington State University, Mount Vernon, WA 98273

${ }^{4}$ Department of Plant Sciences, University of Tennessee, Knoxville, TN 37996

Current address for M.B.A.: Air Quality Research Center, University of California, Davis, CA 95616

We gratefully acknowledge financial support from the U.S. Department of Agriculture Specialty Crops Research Initiative (Award 2014-51181-22382) and National Institute of Food and Agriculture Hatch project 1008680. We thank BioBag Americas (Dunedin, FL), Organix Solutions (Maple Grove, MN), and Yield 10 Bioscience (Woburn, MA) for the kind donation of biodegradable mulch films to our study. We thank Dan Martens (Novamont North America, Shelton, CT) and Sara Guerrini (Novamont S.p.A., Novara, Italy) for technical assistance and Kaitlyn Mckensie Nelms and Leah Dunlap at University of Tennessee for assisting on the physical and chemical properties assessment of the mulches. We thank Elizabeth Cousins, B.J. DeLozier, Cody Fust, Payton Myers, Jake Seeley, and Madelyn Wood for invaluable help with field work at the University of Tennessee and technical assistance by Ed Scheenstra, Lydia Tymon, and Babette Gundersen at Washington State University. Any opinions, findings, conclusions, or recommendations expressed in this article are those of the authors and do not necessarily reflect the view of the funding agencies.

D.G.H. is the corresponding author E-mail: dhayes1@utk.edu.

This is an open access article distributed under the CC BY-NC-ND license (https://creativecommons. org/licenses/by-nc-nd/4.0/).

https://doi.org/10.21273/HORTTECH04922-21 90-d field trial for the production of sweet pepper (Capsicum annumm). In a marine environment, the surface degradation of poly (3-hydroxybutyrate-co-3hydroxyvalerate) was lower at 4 and $20^{\circ} \mathrm{C}$ than at $40^{\circ} \mathrm{C}$ due to an increase of hydrolysis at higher temperatures (Deroiné et al., 2014). The two studies assessed the degradation of BDMs attributable to environmental factors that contribute to physical and chemical aging of plastics; however, to our knowledge, the aging of mulches kept in long-term storage has not yet been evaluated.

The objective of this study was to assess the impact of aging on mulch films' tensile and molecular integrity during storage and the performance of the stored mulches for crop production through field trials. Our hypothesis was that BDMs that are commonly used in North America for vegetable production would slowly degrade during a 3-year indoor storage period, leading to increased degradation when deployed in the field.

\section{Materials and methods}

Materials. The four black mulches employed in the study were obtained by both laboratories involved with this study in Mar. 2015, from the same lot of product for each manufacturer. Among the three BDMs, two commercial products, BioAgri (BioBag Americas, Dunedin, FL) and Organix A.G. (Organix Solutions, Maple Grove, $\mathrm{MN}$ ), contained polybutylene adipate terephthalate (PBAT) as their major component. The third BDM was an experimental PLA/PHA film prepared for this project by Yield10 Bioscience (Woburn, MA). A conventional PE mulch (Filmtech, Allentown, PA) was included as a control. Further information on the thickness, tensile properties, and polymeric composition of the mulches can be found in Table 1 (Anunciado et al., 2021; Hayes et al., 2017). All solvents used to determine physicochemical properties (e.g., hydrogenated and deuterated chloroform) were high-performance liquid chromatography (HPLC) grade (Fisher Scientific, Pittsburgh, PA).

\section{Mulch STORAGE CONDITIONS} AND SAMPLING. The mulch rolls were stored indoors horizontally under controlled conditions in laboratories at the University of Tennessee (UT), Knoxville and at the Northwestern
Washington Research and Extension Center (NWREC), Washington State University (WSU), Mount Vernon. Average storage temperatures in Knoxville were $18 \pm 2.1^{\circ} \mathrm{C}$ in $2016,22 \pm$ $2.0^{\circ} \mathrm{C}$ in 2017 , and $18 \pm 2.1^{\circ} \mathrm{C}$ in 2018, whereas in Mount Vernon, the average temperature was $21 \pm 1.4^{\circ} \mathrm{C}$ from 2015 to 2018 . Relative humidity $(\mathrm{RH})$ in TN was $47 \% \pm 13.0 \%$ (2016), $56 \% \pm 9.2 \%(2017)$, and $32 \% \pm 8.7 \%$ (2018). In Washington, RH was slightly lower and less variable, averaging 39\% across years (2015-18). Mulches were covered by perforated bubble wrap (Grainger, Lake Forest, IL), then placed in metallic-lined bags (Bemis Shield Pack Specialty Packing, West Monroe, LA) to protect the films from light exposure and photodegradation. In February or March of each year (2015-18), a sample was retrieved from each mulch roll at UT and WSU for physicochemical analyses: a 3-m length of mulch was unrolled and discarded, then a l-m length of mulch was collected. Machine direction (MD), the direction in which the mulch unrolls, and cross machine direction (CD), perpendicular to the length of the roll, were marked during sample retrieval from mulch rolls.

Tensile properties. Tensile properties are parameters measured to determine structural integrity of the mulches, which provide quantifiable data that reflect the weakening and embrittlement of the mulch. Tensile tests were performed on subsamples obtained by cutting the samples collected from each laboratory along the MD. Six subsample replicates (15.24$\mathrm{cm} \mathrm{CD} \times 17.78-\mathrm{cm} \mathrm{MD)}$ were tested for each mulch film and time. Peak load and percent elongation at maximum tensile stress were carried out using an electrochemical universal testing machine (model 5567; Instron, Norwood, MA) according to a standardized procedure using a load cell of 10,000 N (ASTM International, 2011).

Molecular weight. The decrease in average molecular weight of the polymers was monitored through gel permeation chromatography (GPC) to detect depolymerization, which is a decrease of the average chain length of polymeric constituents. Weight-averaged molecular weight $\left(M_{\mathrm{w}}\right)$ and polydispersity index (PDI) were obtained for the major polymeric components of 


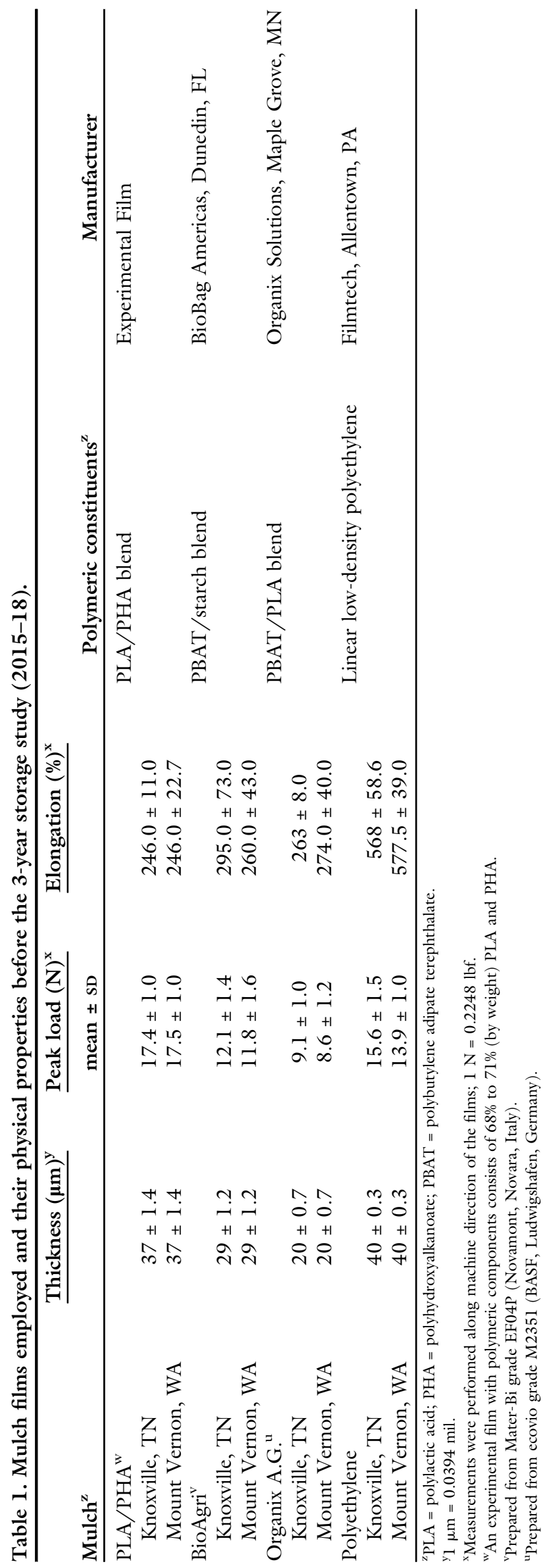

PLA/PHA and BioAgri BDMs, PLA, and PBAT, respectively. Organix A.G., due to poor dissolution in solvents, was excluded from the GPC analysis. The HPLC system employed for GPC (Shimadzu, Columbia, MD) was equipped with a model Mark III evaporative light scattering detector (WR Grace, Deerfield, IL) and a $300 \times 7.5-\mathrm{mm}$ ID PL Gel mixed D column (Agilent Technologies, Santa Clara, CA). Each mulch sample $(20 \mathrm{mg})$ was dissolved in $5 \mathrm{~mL}$ of chloroform and filtered $(20 \mu \mathrm{m}, 1.0 \mu \mathrm{m})$; a $200-\mu \mathrm{L}$ aliquot was injected into the system. Chloroform at a flow rate of $0.8 \mathrm{~mL} \cdot \mathrm{min}^{-1}$ served as the mobile phase, and the run time was $13 \mathrm{~min}$. Polystyrene molecular weight standards (EasiVial PS-H, Agilent Technologies) were used for calibration of the column.

FOURIER-TRANSFORM INFRARED. The surface chemistry of mulch films was determined qualitatively by Fourier-transform infrared (FTIR) spectroscopy using a spectrometer (IRAffinity-1， Shimadzu) equipped with a single reflection attenuated total reflectance detector (MIRacle ATR; PIKE Technologies, Madison, WI), over the range of 4000 to $650 \mathrm{~cm}^{-1}$ and with a spectral resolution of 4 $\mathrm{cm}^{-1}$. Sixteen scans were analyzed for each of four replicate subsamples, with the shinier side of the films (which typically face upward when mulches are laid) being analyzed. Spectral data were normalized by equating the integrated peak area of the entire spectrum to 1.0 (i.e., mean normalization).

Thermal properties. Thermal properties of BDMs were determined by thermogravimetric analysis instrument (Discovery; TA Instruments, New Castle, DE). Samples $(\approx 2 \mathrm{mg})$ were placed in an unsealed platinum sample pan under a nitrogen atmosphere. The scanning speed was $10{ }^{\circ} \mathrm{C} / \mathrm{min}$, and the temperature, controlled using an aluminum sample port, ranged from 25 to $600^{\circ} \mathrm{C}$.

EXPERIMENTAL FIELD TRIALS. Experimental plots were established in 2017 and 2018 at the UT East Tennessee AgResearch and Education Center, Plant Sciences Unit, Knoxville, TN (lat. $35^{\circ} 52^{\prime} 52^{\prime \prime} \mathrm{N}$, long. $83^{\circ} 55^{\prime} 27^{\prime \prime} \mathrm{W}$ ) and the WSU NWREC in Mount Vernon, WA (lat. $48^{\circ} 43^{\prime} 24^{\prime \prime} \mathrm{N}$, long. $122^{\circ} 39^{\prime} 09^{\prime \prime} \mathrm{W}$ ). Crops grown on the mulch were bell pepper (C. annumm) in Knoxville 
and pie pumpkin (Cucurbita pepo) in Mount Vernon. Plots were not replicated as crop productivity was not the focus of this study. However, the stored mulch field studies allowed us to observe the impact of aging on mulch degradation, both of which are indicators of mulch performance. Concurrently, we performed replicated field studies using the same mulching treatments at both sites for both years, but which used new mulch rolls, obtained in early 2017 (new mulch field study). The test crops for the new mulch field study was bell pepper in Knoxville and sweet corn (Zea mays) in Mount Vernon. More detailed information on the new mulch field study and environmental data for both studies are provided elsewhere (Anunciado et al., 2021; Ghimire et al., 2018; Moore and Wszelaki, 2019).

For the stored mulch studies in Knoxville, a nonreplicated field trial with one raised bed per mulching treatment (each mulch bed $25 \mathrm{ft}$ long, with a 2 -ft buffer between mulch types; total row length was $135 \mathrm{ft}$ ) was established using a bed shaper (model 2600; Rain-Flo Irrigation, East Pearl, PA). Beds were 6 to 8 inches high and 32 inches wide at the bottom ( 24 inches at the top), with a 5 -ft buffer between plots in each row (average of 10 measurements). After disking the field but before mulch laying, fertilizer was applied to the field with a $10-\mathrm{ft}$ drop spreader and incorporated into the soil with a field cultivator. Total amounts of macronutrients applied were (through a combination of soilapplied and fertigation): $177 \mathrm{lb} /$ acre nitrogen $(\mathrm{N}), 43.7 \mathrm{lb} /$ acre phosphorus $(\mathrm{P})$, and $188 \mathrm{lb} /$ acre potassium (K). Preemergence herbicides were applied before shaping beds and laying mulches and postemergence herbicides were applied between beds to the row middles for weed control. Weed control was also supplemented by hoeing and hand weeding as needed throughout the growing season. Mulch rolls were laid by machine in all plots. Drip irrigation tape [dripper spacing 8 inches, flow rate 0.34 $\mathrm{gal} / \mathrm{min}$ per $100 \mathrm{ft}$ (T-Tape model \#508-08-340; T-Systems International, San Diego, CA)] was laid simultaneously with the mulch laying. 'Aristotle' bell pepper seeds (Seedway,
Hall, NY) were sown in 128-cell trays in the greenhouse on 21 and 22 Apr. 2017 and 17 and 18 Apr. 2018, and transplanted to the field on 25 May 2017 and 29 May 2018. Transplant holes were 2 inches diameter and 1 inch deep, punched by hand in a double staggered row 12 inches apart and with 18 inches between plants in the row. Each plot contained 37 plants staked with a Florida weave system.

In Mount Vernon, a nonreplicated field trial with two mulching treatments per raised bed was established using a bed shaper (model 2600). Beds were 6 to 8 inches high and 32 inches wide at the bottom (24 inches at the top), and $105 \mathrm{ft}$ long. Each plot was $50 \mathrm{ft}$ long and there was a 5 - $\mathrm{ft}$ nonmulched area between mulch treatments. Fertilizer (10N-4.4P-8.3K; Super 16-16-16 plus S, Schultz, Knox, IN) was applied at the rate of $100 \mathrm{lb} /$ acre $\mathrm{N}$ in 2017 and $105 \mathrm{lb} /$ acre $\mathrm{N}$ in 2018 to the center of each row, before the beds were raised and the mulch laid; the mulch layer incorporated the fertilizer. Mulch rolls were laid by machine at the same time as bed shaping. Drip irrigation tape (model \#508-08-340) was placed simultaneously with the laying of the mulch treatments. 'Cinnamon Girl' pie pumpkin (Johnny's Selected Seed, Winslow, ME) were seeded in 72-cell trays in the greenhouse on 9 May 2017 and 8 May 2018 and transplanted to the field after 3 weeks. Transplant holes were punched by hand with a wooden dibble in a single row, offset of the center in each plot, with 17 holes per plot. Holes were 2 inches in diameter and 2 to 3 inches deep. Extra transplants were moved to 4 -inch pots the week after transplanting so that plant size was equivalent to the size of plants in the field. Plants in the field were replaced as needed for up to 4 weeks after transplanting due to bird damage. Alleys and sides of beds were mechanically cultivated to control weeds until vine growth prevented further cultivation.

MulCH PERFORMANCE ASSESSMENT. To determine the effects of storage on structural integrity of the mulches during field use, the extent of degradation in relation to horticultural performance of the mulches was assessed through mulch degradation ratings using the percent soil exposure (PSE) technique. The PSE of each mulch treatment was recorded in the center $\mathrm{l} \mathrm{m}$ of each field plot two times per month. PSE was assessed such that $0 \%$ represented soil that was completely covered by mulch and 100\% represented fully exposed soil. Ratings were in $1 \%$ increments up to $20 \%$ PSE and in $5 \%$ increments thereafter (Ghimire et al., 2018).

Statistical analysis. Tensile properties of mulches taken from the same mulch roll (left, middle, and right sections) were subjected to repeated measure analysis of variance using mixed-model procedure (year nested to mulches). Group means differences were compared using Tukey honestly significant difference test at $5 \%$ level of significance. The statistical analyses were performed using statistical software (JMP version 16; SAS Institute, Cary, NC). The complete randomization of mulch samples for measurement of physicochemical properties was not possible due to the availability of only a few mulch rolls. The PSE scores on yearly cropping season are reported directly.

\section{Results and discussion}

Changes of Tensile PROPERTIES OF BDMS DURING 3 YEARS OF storage. Peak load values for BDMs and PE mulch, determined under standard test conditions at 1-year intervals (2015-18), are presented in Fig. 1. Peak load reflects the tensile strength of the mulches as they are stretched laterally. PBAT-based BDMs (BioAgri and Organix A.G.) underwent a large reduction of peak load under storage in both laboratories, whereas PLA/PHA underwent a much smaller change of peak load. In Knoxville, BioAgri had a greater decrease of peak load (33\%) than Organix A.G. $(20 \%)$ in $2017(P<$ $0.0001)$, and the decrease for BioAgri began earlier, in $2016(P<0.0001)$. Similar to Knoxville, peak load of mulches in Mount Vernon did not change significantly during years 1 and 2 , and a large decrease occurred in year 3 for PBAT-based BDMs, with a larger reduction in peak load for BioAgri $(P<0.0001)$ than Organix A.G. $(P=0.004)$. Although there were no changes in peak load for PLA/PHA $(P=0.20)$ in Tennessee, a significant reduction $(P=0.02)$ occurred in Mount Vernon from 2017 to 2018, but also a slight increase of peak load was observed in 2016 and 2017. The slight increase 

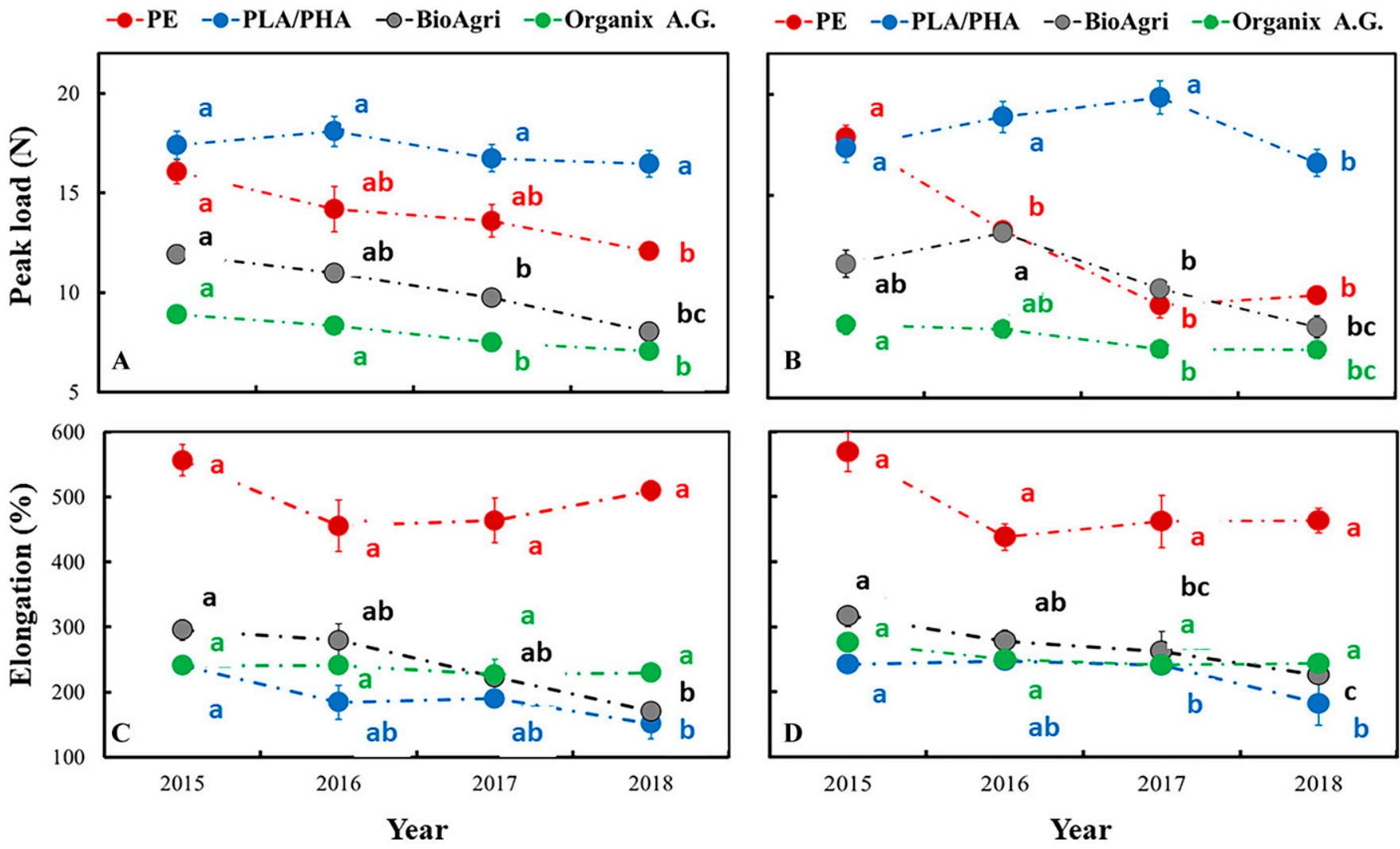

Fig. 1. (A, B) Changes of peak load and (C, D) elongation of mulches during 3-year storage in laboratories in (A, C) Knoxville, TN, and (B, D) Mount Vernon. PE = polyethylene mulch film; PLA/PHA = experimental soil-biodegradable mulch (BDM) composed of polylactic acid (PLA) and polyhydroxyalkanoate (PHA); BioAgri and Organix A.G. = commercially available BDMs manufactured by BioBag Americas (Dunedin, FL) and Organix Solutions (Maple Grove, MN), respectively. Further information on the BDMs is available in Table 1. Error bars reflect SE (six replicates) and means that do not share common letters for each mulch reflect statistically significant difference, as determined through repeated measure analysis of variance using a mixed-model procedure (year nested to mulches). Group means differences were compared using Tukey honestly significant difference test at $5 \%$ level of significance. For several data points, the error bars are smaller than the size of the markers. Statistical analysis was performed for each mulch separately in a given location, with year as a factor; $1 \mathrm{~N}=0.2248 \mathrm{lbf}$.

may be attributed to variability in the samples taken from mulch rolls or between batches of mulch rolls sent to the two locations, particularly for the PLA/PHA experimental film. Significant reduction in peak load was measured for PE mulch in both locations in certain years $[2018$ for Knoxville $(P$ $=0.03), 2016$ for Mount Vernon $(P=$ $0.001)]$. In summary, even under ideal conditions, after 1 year of storage, BDMs underwent a significant reduction in tensile strength.

Percent elongation is the ratio of the specimen's initial length and the length of the mulch film specimen as it is stretched laterally up to the occurrence of breakage, multiplied by $100 \%$. A decrease of elongation with time, which indicates embrittlement, was observed for BioAgri and PLA/PHA at both storage locations, but not for Organix A.G. nor for PE mulch at either location (Fig. 1). The greatest decrease of elongation for BioAgri and PLA/PHA occurred between years 2 and 3 of storage (2017-18) at both locations. Between the beginning and end of the 3 -year period, elongation was reduced to a greater extent for BioAgri $(P=$ 0.0005 and $P<0.0001$ ) than for PLA/PHA $(P=0.006$ and $P=0.02)$ in Knoxville and Mount Vernon, respectively. A similar loss of tensile properties, particularly for elongation at break, was also observed for Mater-Bi (Novamont, Novara, Italy)-based BDMs at $-18^{\circ} \mathrm{C}$ (Briassoulis and Giannoulis, 2018).

ChANGes OF CHEMICAL PROPERTIES OF MULCHES DURING 3 YEARS OF STORAGE. Average molecular weight and PDI for PLA and PBAT of the PLA/PHA and BioAgri, respectively, obtained through GPC, were monitored during the 3 year storage period (2015-18) (Table $2)$. PDI represents the degree of heterogeneity in molecular weight between polymer molecules in a given plastic material. $M_{w}$ of PLA was significantly different between storage locations $(P<0.0001)$ and across years of storage $(P<0.0001)$. $\mathrm{M}_{\mathrm{w}}$ of PLA initially increased after years 1 and 2 in both locations. The increase may reflect the release of lower-molecular-weight oligomers and monomers resulting from increased embrittlement of the BDMs during storage. Similarly, for the same polymer, an increase of $\mathrm{M}_{\mathrm{w}}$ was also reported during the initial phase of biodegradation and environmental weathering (Anunciado et al., 2021; Dharmalingam et al., 2016). The $M_{w}$ for PLA/PHA started to decrease significantly after year 2 of storage for both locations, indicating hydrolysis of the polymer's ester bonds. For BioAgri, the $M_{w}$ of PBAT significantly decreased in 2017 in Knoxville and in 2018 in Mount Vernon 
Table 2. Change of weight-averaged molecular weight $\left(\mathrm{M}_{\mathrm{w}}\right)$ and polydispersity index (PDI) via gel permeation chromatographic analysis of two soil-biodegradable mulches at two different locations during 3 years of storage. Values are based on two replicates.

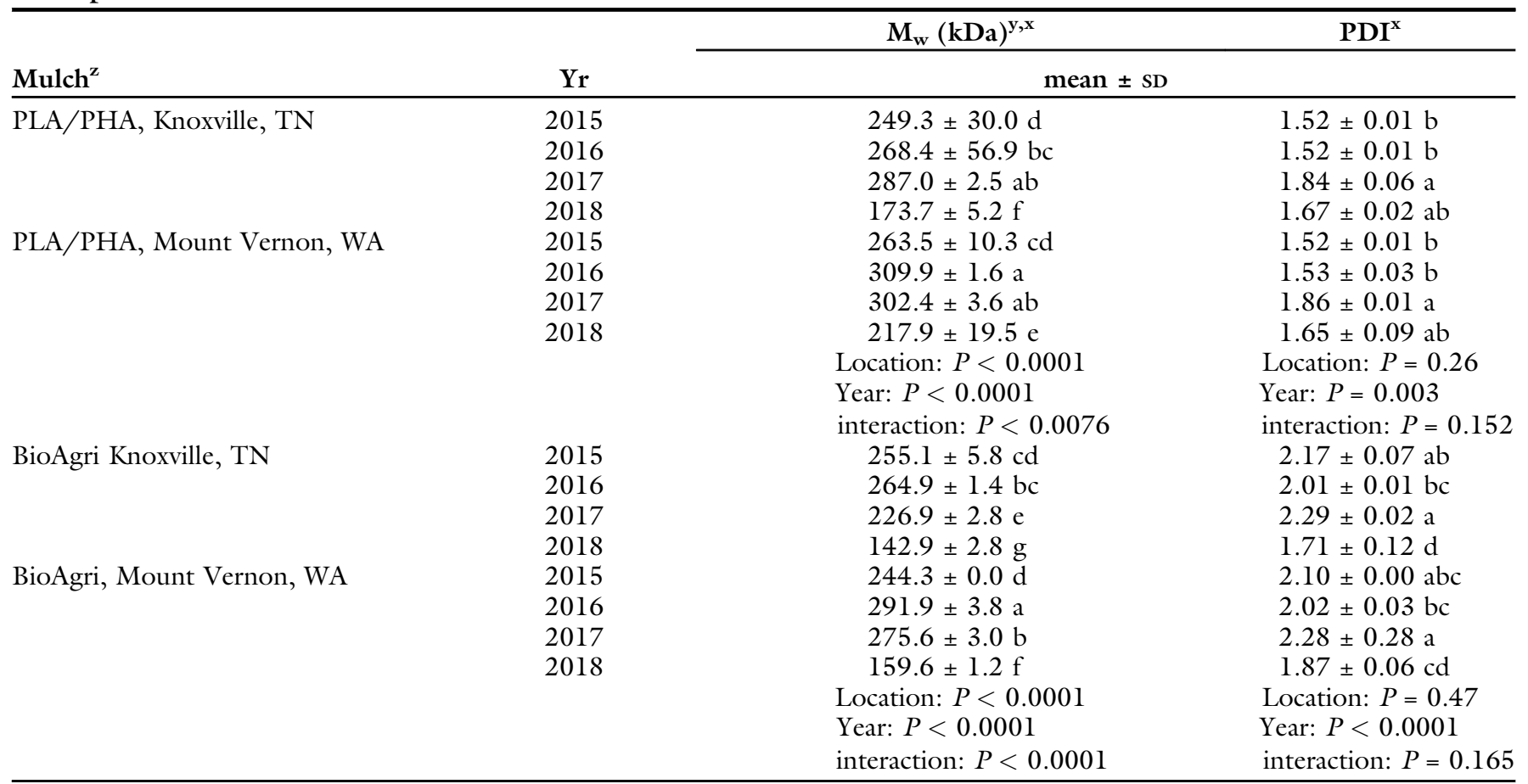

${ }^{\mathrm{z}} \mathrm{PLA} / \mathrm{PHA}=$ experimental soil-biodegradable mulch composed of polylactic acid (PLA) and polyhydroxyalkanoate (PHA); BioAgri = soil-biodegradable mulch composed of a polybutylene adipate terephthalate/starch blend (Biobag Americas, Dunedin, FL).

${ }^{\mathrm{y}} 1 \mathrm{kDa}=1000 \mathrm{~g} \cdot \mathrm{mol}^{-1}$.

${ }^{\mathrm{x}}$ Values are based on two replicates; means that do not share common letters for each mulch reflect statistically significant difference.

Table 3. Peak assignments for Fourier transfer IR analysis of soil-biodegradable mulches.

\begin{tabular}{lll}
\hline Wavenumber $\left(\mathrm{cm}^{-\mathbf{l}}\right)^{\mathbf{z}}$ & \multicolumn{1}{c}{ Mulch $^{\mathbf{y}}$} & \multicolumn{1}{c}{ Contribution } \\
\hline 1746 & PLA/PHA & Carbonyl $(\mathrm{C}=\mathrm{O})$ stretch \\
1712 & BioAgri, Organix A.G. & C=O stretch (polyester) \\
1646 & BioAgri & C=O stretch (polysaccharide) \\
$1456,1410,1390$ & BioAgri, Organix A.G. & Methylene $\left(-\mathrm{CH}_{2}-\right)$ bend \\
1448 & PLA/PHA & Methyl $\left(\mathrm{CH}_{3}\right)$ bend \\
1384,1356 & PLA/PHA & deformation of $\alpha$-carbon-hydrogen $(-\mathrm{CH}-)$ bond \\
1304,1264 & PLA/PHA & C=O bend \\
$1268,1252,1166$, & BioAgri, Organix A.G. & Carbon-oxygen $(\mathrm{C}-\mathrm{O})$ stretch \\
$1118,1102,1082$ & BioAgri, Organix A.G. & C-O stretch \\
$1180,1128,1082$ & PLA/PHA & C-O stretch \\
$1076-1000$ & PLA/PHA, BioAgri, Organix A.G. & Oxygen-hydrogen $(\mathrm{O}-\mathrm{H})$ bend \\
874 & PLA/PHA, BioAgri, Organix A.G. & C-H stretch \\
728 & BioAgri, Organix A.G. & CH bend of butanediol monomer \\
\hline
\end{tabular}

${ }^{\mathrm{z}}$ Values taken from (Hayes et al., 2017); $1 \mathrm{~cm}=0.3937$ inch.

${ }^{\mathbf{y}}$ PLA/PHA $=$ experimental soil-biodegradable mulch composed of polylactic acid $($ PLA $)$ and polyhydroxyalkanoate $($ PHA $)$; BioAgri = soil-biodegradable mulch composed of a polybutylene adipate terephthalate (PBAT)/starch blend (Biobag Americas, Dunedin, FL); Organix A.G. = soil-biodegradable mulch composed of a PBATPLA blend (Organix Solutions, Maple Grove, MN).

compared with previous years. $\mathrm{M}_{\mathrm{w}}$ values were significantly different between storage locations $(P<0.0001)$ and across years $(P<0.0001)$. PDI slightly increased after year 2 of storage in both locations (2017) for both PLA/PHA and PBAT but was not significantly different between locations. PDI changes were significant across years of storage for PLA/PHA $(P=0.003)$ and
BioAgri $(P<0.0001)$. The observed increase of PDI is consistent with the occurrence of hydrolysis of ester bonds, leading to an increase in the proportion of lower molecular weight molecules.

FTIR spectroscopy provides information on changes of chemical bonding occurring on the surface of mulches, specifically pertaining to degradation of the material. The frequency of spectral bands corresponds to specific chemical bonds and the band intensities reflect relative concentrations of the bonds. FTIR spectra can indicate changes of chemical bonding and changes in the relative amounts of polymeric constituents as mulch films age. Spectral band assignments are given in Table 3. 

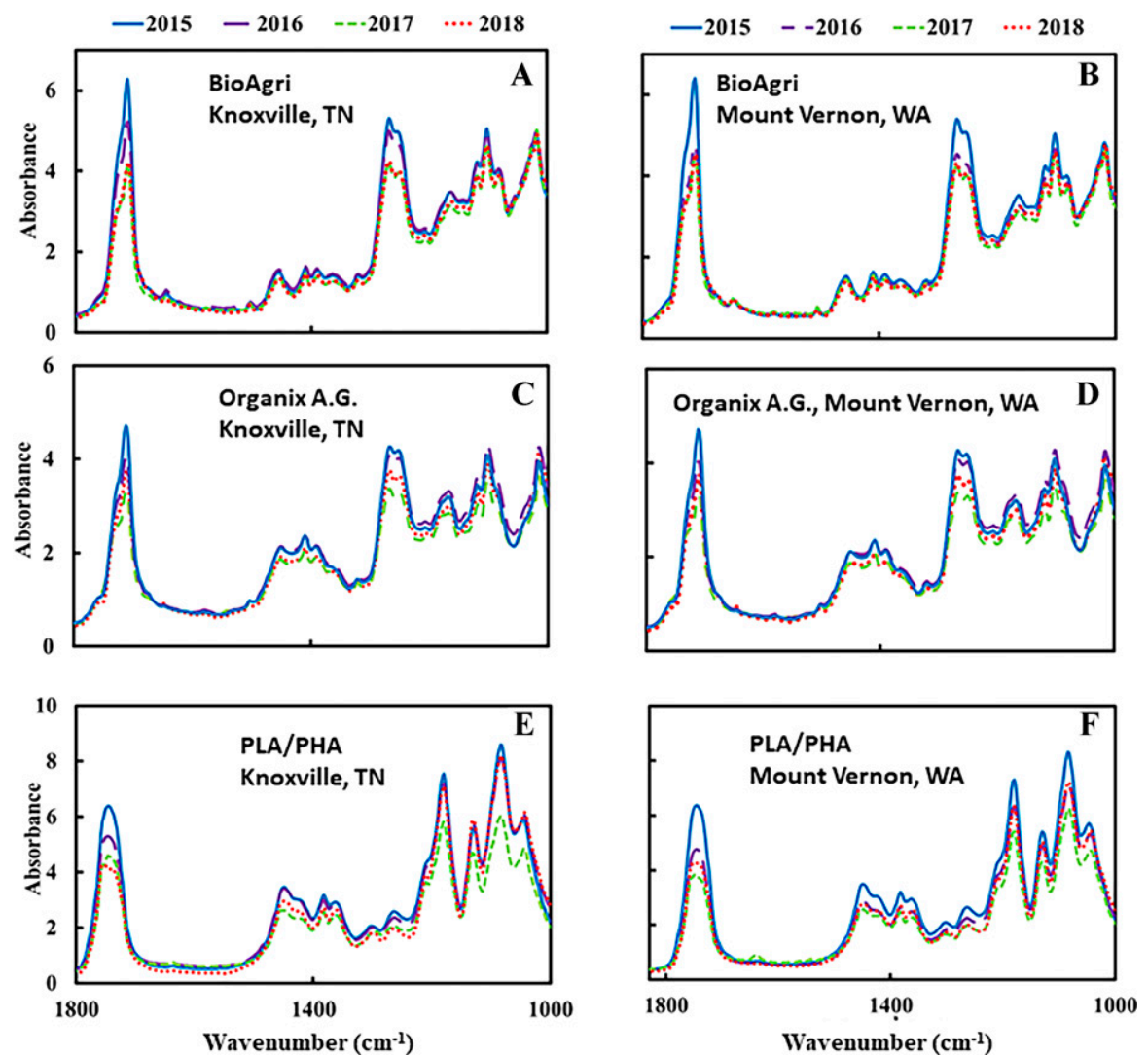

Fig. 2. Changes of Fourier transform infrared spectra $\left(1800-1000 \mathrm{~cm}^{-1}\right)$ of soilbiodegradable mulches (BDMs) during 3-year storage (2015-18) in laboratories in (A, C, E) Knoxville, TN, and (B, D, F) Mount Vernon, WA: BDMs (A, B) BioAgri (Biobag Americas, Dunedin, FL), (C, D) Organix A.G. (Organix Solutions, Maple Grove, MN), and (E, F) PLA/PHA (experimental film prepared from a polylactic acid/polyhydroxyalkanoate blend). Further information on the BDMs is available in Table $1.1 \mathrm{~cm}=0.3937 \mathrm{inch}$.

Evidence from FTIR analysis suggests minor degradation of BDMs due to hydrolysis (Fig. 2). For PBAT-based BDMs, most spectral changes occurred only after year 2 of aging. No differences in trends for FTIR spectral regions between years were observed for BioAgri at either location. For Organix A.G., large increases in the oxygen-hydrogen $(\mathrm{O}-\mathrm{H})$ stretching region and methylene $\left(\mathrm{CH}_{2}\right)$ bending region of PBAT's butanediol monomers were observed in Mount Vernon, and for both locations, a decrease of carbon-oxygen (C-O) stretching, methylene $\left(-\mathrm{CH}_{2}^{-}\right)$bending, and carbon-hydrogen $(\mathrm{C}-\mathrm{H})$ stretching regions of Organix A.G. were observed (Fig. 2C and D). For PLA/PHA, pronounced spectral changes occurred after year 1 of storage in both locations: the peak intensity of ester-related bonds of PLA/PHA [carbonyl $(\mathrm{C}=\mathrm{O})$ stretch, methyl $\left(\mathrm{CH}_{3}\right)$ bend, deformation of the $\alpha-\mathrm{CH}$-bond, $\mathrm{C}=\mathrm{O}$ bend and $\mathrm{C}-\mathrm{O}$ stretch] decreased during storage at both facilities (Fig. 2E and F). In addition, the peak intensity of oxygen-hydrogen $(\mathrm{O}$ $\mathrm{H})$ stretching bands $\left(3800-3010 \mathrm{~cm}^{-1}\right)$ increased in intensity with time at both storage locations, reflecting the formation of free $-\mathrm{OH}$ end groups (Fig. 3). Another important spectral feature for PLA/PHA in Mount Vernon was the formation of a small peak $\left(1650 \mathrm{~cm}^{-1}\right)$ that likely represents the carbonyl stretch of free $\mathrm{COOH}$ (end) groups (Fig. 2E). All FTIR spectral changes indicate hydrolysis of ester bonds, consistent with the decrease of $\mathrm{M}_{\mathrm{w}}$ (Table 2) and not due to ultraviolet exposure. Changes in the FTIR spectra of mulch film surfaces during storage are not associated with photochemical reactions, which strongly promote degradation of mulches in the field through exposure to sunlight (Anunciado et al., 2021).

Thermogravimetric analysis measures the mass loss of the plastic material as the temperature is slowly and steadily increased $\left(10^{\circ} \mathrm{C} / \mathrm{min}\right.$ for this study) to above the boiling point temperatures of the polymers. Differential thermograms
(DTGs), depicting the rate of mass loss versus temperature, consist of bands referred to as "heating stages," which represent different components. DTGs of BDMs during 3 years of indoor storage in Knoxville and Mount Vernon are shown in Fig. 4. The relative areas for the heating stages reflect the relative concentration of the components. For BioAgri, the two heating stages that occur at 310 and $400^{\circ} \mathrm{C}$ reflect its two major polymeric components, starch and PBAT, respectively, while Organix A.G. contains only one major heating stage, near $400^{\circ} \mathrm{C}$, for PBAT (Fig. $4 \mathrm{~A}-\mathrm{D})$. The two heating stages observed in the DTGs of PLA/PHA, at 270 and $320^{\circ} \mathrm{C}$, represent PHA and PLA, respectively (Fig. 4E and F). Several of the DTG heating stages shifted to higher or lower temperatures with increased storage time, reflecting an increase or decrease of thermostability, respectively (Fig. 4). A decrease of thermostability can reflect depolymerization (i.e., a $M_{w}$ decrease) or a decrease in crystallinity.

The thermal stability of PBAT and starch in BioAgri and PBAT in Organix A.G. slightly increased for both storage locations for 2018 compared with previous years (Fig. $4 \mathrm{~A}-\mathrm{D})$. The change was more extensive for starch, noticeable after year l of storage (2016) in both TN and WA. This trend is likely attributable to the release of lower molecular weight polymer molecules from the mulch. However, the trend contrasts the observed decrease of $M_{w}$ for PBAT (Table 2). Perhaps the decrease of thermostability for PBAT due to hydrolysis was counterbalanced by an increase of crystallinity, due to the selective release of low molecular weight polymer molecules. The DTGs show a difference in the thermal stability of PLA/PHA mulches starting after year 1 of storage (2016), particularly a major decrease of thermostability for PHA, reflecting that PHA is more susceptible to hydrolysis than PLA, and a broadening of both heating stages in 2018 (Fig. 4E and F), indicating broadening of the molecular weight distribution due to hydrolysis, consistent with the observed increase of PDI (Table 2). A loss of thermal stability is often indicative of depolymerization, which can lead to degradation of mulches in the field. 

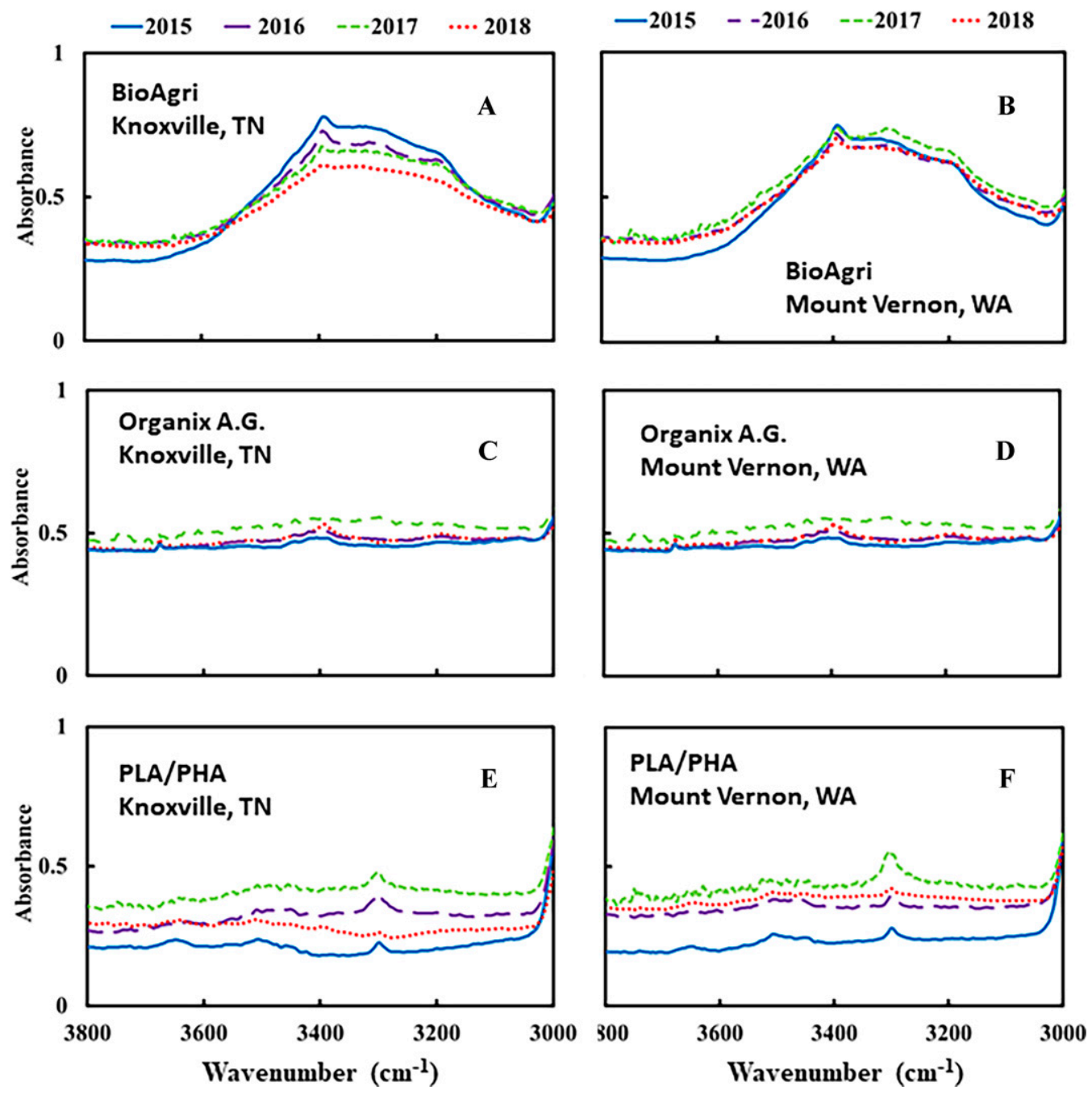

Fig. 3. Changes of Fourier transform infrared spectra $\left(3800-3000 \mathrm{~cm}^{-1}\right)$ of soil-biodegradable mulches (BDMs) during 3year storage (2015-18) in laboratories in (A, C, E) Knoxville, TN, and (B, D, F) Mount Vernon, WA during 3-year storage (2015-18): BDMs (A, B) BioAgri (Biobag Americas, Dunedin, FL), (C, D) Organix A.G. (Organix Solutions, Maple Grove, MN), and (E, F) PLA/PHA (experimental film prepared from a polylactic acid/polyhydroxyalkanoate blend). Further information on the BDMs is available in Table $1.1 \mathrm{~cm}=0.3937 \mathrm{inch}$.

EFFECT OF BDM AGING ON HORTICULTURAL PERFORMANCE: EVALUATION OF PSE AND CROP YIELD. Visual assessment is used to evaluate how well mulches remain intact over time and provides an indication of mulch degradation during field trials (Cowan et al., 2016). PSE is a measure of the area of soil exposed relative to intact mulch area as mulches are subjected to rips, tears and punctures in the field (Cowan et al., 2016, Ghimire et al., 2018; Miles et al., 2017). PSE scores were much higher in Knoxville than in Mount Vernon (Fig. 5), likely due to environmental conditions in TN that contributed to more rapid weathering of BDMs (e.g., higher soil and air temperature and higher relative humidity) (Anunciado et al., 2021). In addition, Knoxville experienced higher weed pressure, particularly from yellow nutsedge [Cyperus esculentus (Ghimire et al., 2018; Moore and Wszelaki 2019)]. PSE ratings in general increased with time and were higher in 2018 than in 2017 for both locations. The highest PSE ratings were observed for BioAgri in 2018: $90 \%$ and $15 \%$ in Knoxville and Mount Vernon, respectively (Fig. 5A and B). The increase of PSE score for BioAgri in Mount Vernon over year 3 was remarkable, with a zero PSE rating observed throughout 2017 (Fig. 5B). Concurrent with the stored mulch field trials described herein, we performed a larger field trial at both locations that employed new mulch rolls, which were obtained in 2017 (Ghimire et al., 2020; Moore and Wszelaki, 2019). The PSE ratings for BioAgri in the new mulch field studies $(40 \%$ to $60 \%$ and $6 \%$ to $8 \%$ for Knoxville and Mount Vernon, respectively) were slightly lower than those observed in the stored mulch field trials (Ghimire et al., 2020; Moore and Wszelaki, 2019). It is noted that the test crops employed for the field studies differed between stored and new mulch trials in Mount Vernon (pie pumpkin and sweet corn, respectively) and between locations, although both the stored and new mulch trials employed bell peppers as the cropping system in Knoxville. Although crop type can influence mulch degradation, the impact of this factor during the early season is minor since plant canopies were not 

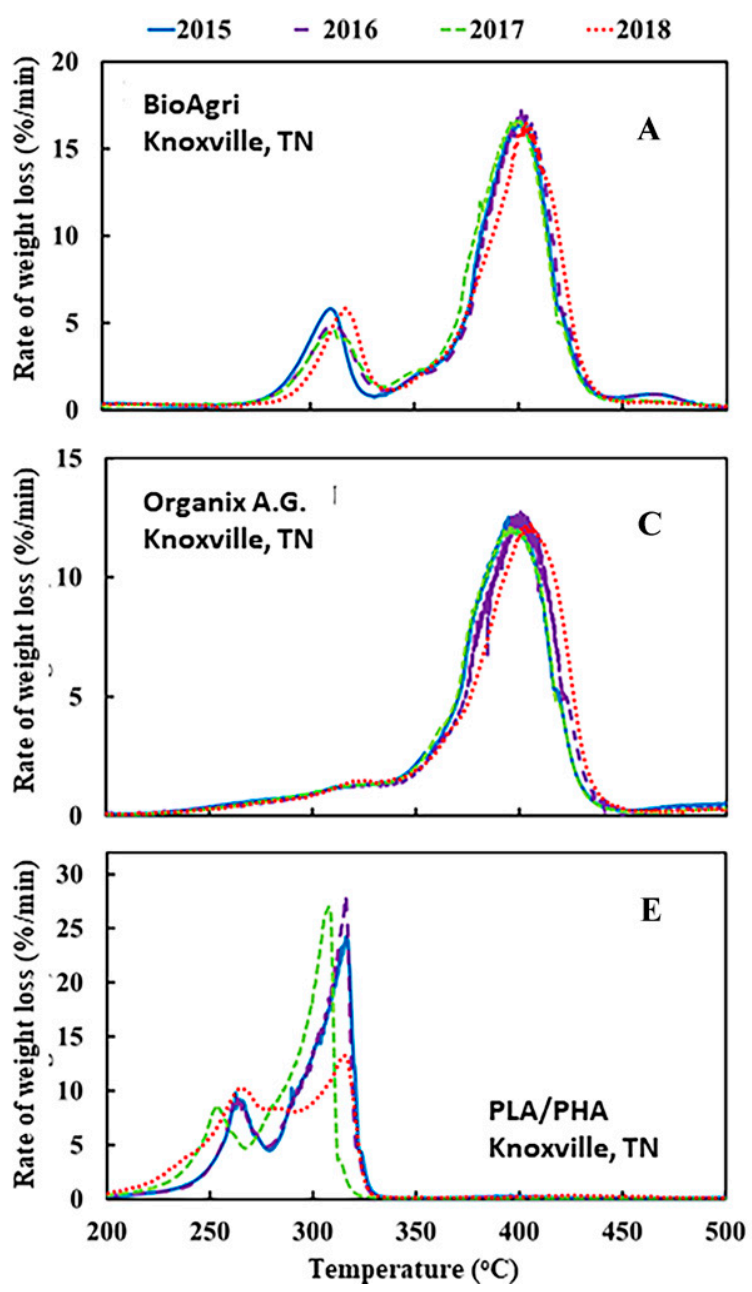
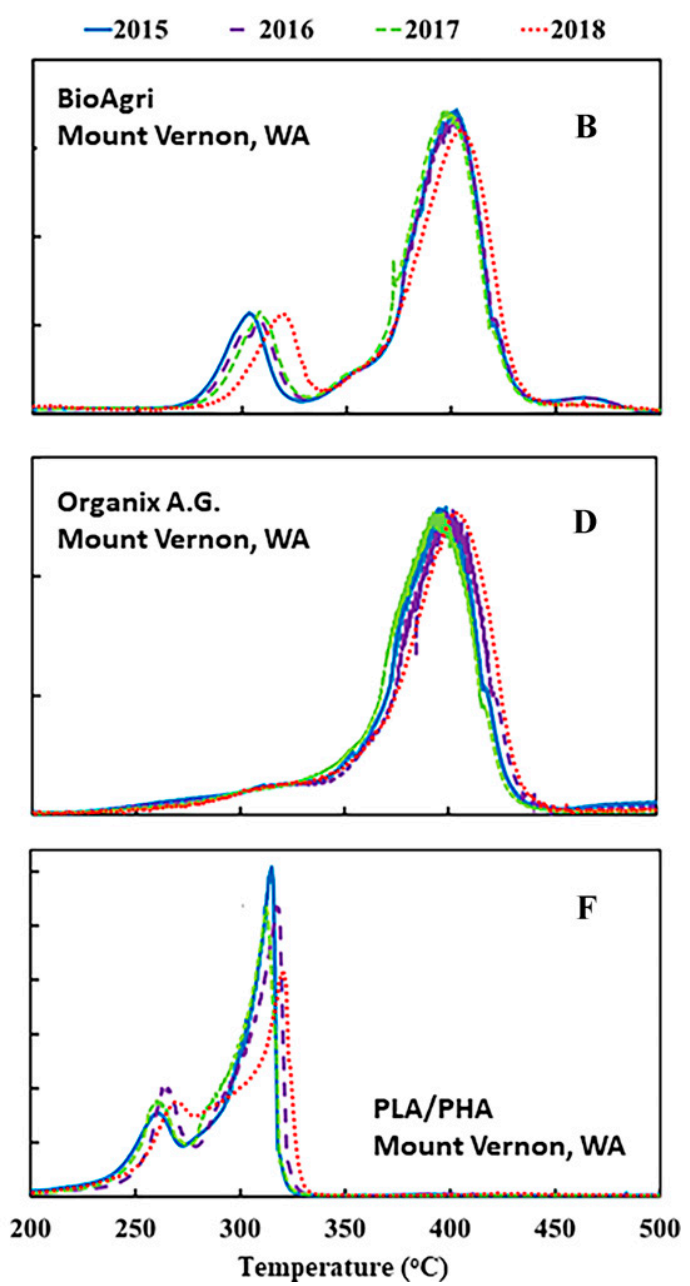

Fig. 4. Changes of the differential thermograms (DTGs) of soil-biodegradable mulches (BDMs) during 3-year storage (2015-18) in laboratories in (A, C, E) Knoxville, TN, and (B, D, F) Mount Vernon, WA: BDMs (A, B) BioAgri (Biobag Americas, Dunedin, FL), (C, D) Organix A.G. (Organix Solutions, Maple Grove, MN), and (E, F) PLA/PHA (experimental film prepared from a polylactic acid/polyhydroxyalkanoate blend). Further information on the BDMs is available in Table 1. Major heating stages: $(\mathrm{A}, \mathrm{B}) 310^{\circ} \mathrm{C},(\mathrm{A}-\mathrm{D}) 400^{\circ} \mathrm{C},(\mathrm{E}, \mathrm{F}) 265^{\circ} \mathrm{C}$, and $(\mathrm{E}, \mathrm{F}) 315^{\circ} \mathrm{C}$, which correspond to starch, polybutylene adipate terephthalate (PBAT), PHA, and PLA, respectively. PLA also appears as a minor shoulder in (C,D); $\left(1.8 \times{ }^{\circ} \mathrm{C}\right)+32={ }^{\circ} \mathrm{F}$.

observed to form until after 5 to 7 weeks (Anunciado et al., 2021).

The PSE scores for Organix A.G. did not increase as rapidly early in the season as BioAgri in Knoxville for the stored mulch field trials, although, by the end of the 2018 season, the PSE rating for Organix A.G. reached $70 \%$ (Fig. 5A). In Mount Vernon, Organix A.G. and BioAgri had similar PSE ratings during the first 2 months of 2018; however, by the end of the season, BioAgri produced a higher PSE (Fig. 5B). PSE ratings for Organix A.G. at both locations for the stored mulch trials were within range of the values observed using new mulch rolls (Ghimire et al., 2018, 2020; Moore and Wszelaki, 2019). For PE mulch, PSE was greater by the end of the season in 2018 (10\%) compared with 2017 (5\%) in Knoxville; but, in Mount Vernon, the difference between years for PE was very slight $(0 \%$ in $2017,1 \%$ in 2018$)$.

Because the PLA/PHA was experimental and not commercially available, new rolls were not obtained, and therefore, the original 2015 rolls were used in the new mulch field trials and so were not included in the stored mulch field study. In Knoxville, a $100 \%$ PSE rating was observed for PLA/PHA mulch by the end of the crop season in 2018, and the increase in PSE was rapid, reaching $>40 \%$ only $17 \mathrm{~d}$ after being laid in the field, which was a much more rapid increase than 2017 (Moore and Wszelaki,
2019). In comparison, in Mount Vernon, the PSE rating of PLA/PHA mulch did not change throughout the growing seasons in 2017 or 2018 (Ghimire et al., 2018).

These results suggest the increase of PSE score in 2018 compared with 2017 for the stored mulch field trials and to the 2018 new mulch field trials is directly linked to degradation during the aging of mulches, particularly during year 3 of storage. Moreover, aging greatly accelerated the onset of degradation of BDMs in the field, especially when deployed in an area with challenging environmental conditions such as Knoxville. The degradation observed in the field reflects the decrease in tensile properties of the BDMs that we observed during storage 

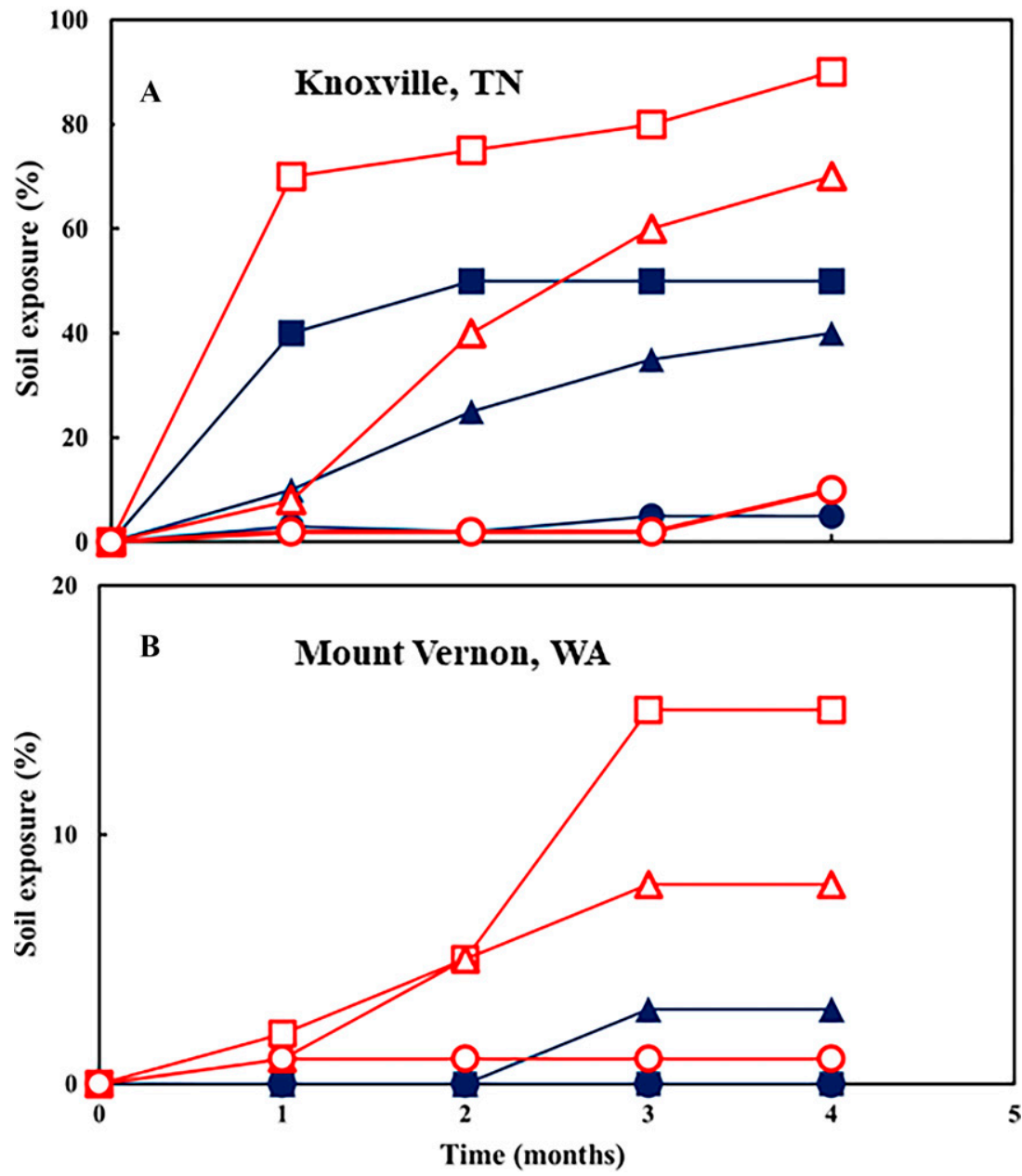

Fig. 5. Percent soil exposure (PSE) of mulches during field trials in 2017 and 2018 after long-term storage in (A) Knoxville, TN, and (B) Mount Vernon, WA. Mulch treatments: BioAgri (polybutylene adipate terephthalate (PBAT)/starch blend; Biobag Americas, Dunedin, FL), Organix A.G. (PBAT/polylactic acid blend; Organix Solutions, Maple Grove, MN), and polyethylene mulch. Mulches were obtained in 2015. Further information on the mulches is given in Table 1.

(Fig. 1). As mulches lose mechanical strength, they become more susceptible to degradation throughout the cropping season (Briassoulis, 2004; Emadian et al., 2017; Vroman and Tighzert, 2009).

The degradation of mulch films can lead to reduced performance in vegetable production. In our field studies, we observed a decreased crop yield for mulching treatments that underwent premature degradation during the early cropping season (Ghimire et al., 2018, 2020; Moore and Wszelaki, 2019). However, the observed differences in PSE scores between most black mulch films (BDMs and PE mulch) for a given cropping season led to only minor impacts on crop yield and quality, in general. Moreover, several other factors more strongly influence differences in crop yields between years, such as environmental conditions (including extreme climatological events such as droughts or severe thunderstorms), pests, diseases, and farming practices.

\section{Conclusions}

To assess the impact of aging on the properties and performance of BDMs, physicochemical properties of three BDMs (two PBAT-based black BDMs that are commercially available in North America: BioAgri and Organix A.G., and an experimental film prepared from PLA and PHA), and PE mulch were measured over a 3-year period under ideal storage conditions at two laboratories and the aged mulches were employed in field trials during years 2 and 3 of the study. BDMs significantly lost tensile strength and elongation after year 1. Hydrolysis of BDMs' polymeric constituents was observed after year 2 of storage via FTIR spectroscopic and GPC analyses, slightly for BioAgri and to a greater extent for PLA/PHA. The thermal stability decreased slightly for the two PBAT-based black BDMs, but was significantly higher for PLA/PHA, which likely reflects depolymerization occurring during mulch storage.

During field trials conducted in both Knoxville, TN, and Mount Vernon, WA, mulches (particularly BioAgri and Organix) underwent degradation to an increasing extent as the cropping seasons progressed, and for year $3 \mathrm{com}-$ pared with year 2 , as observed through PSE ratings. In summary, this study demonstrates that BDMs undergo degradation of tensile and chemical properties when stored for 1 year or longer and that long-term storage before fielduse led to more rapid degradation in the field than for new mulch rolls after year 2 .

BDMs used in our study underwent degradation, even when stored under ideal conditions, and the extent of degradation was particularly high between years 2 and 3 of storage. Our results suggest that mulches typically used for vegetable production in North America not be used beyond 2 years of the receipt date, and this requirement pertains to ideal storage conditions and practices, such as indoors under controlled temperature and humidity and covered to prevent light degradation. It is important that a specialty crop grower order only as much mulch as needed for a given year and, if rolls are left over, these should be used first the following year. Therefore, a grower should keep track of receipt dates and lot numbers for mulch rolls received. The latter can be used to track the manufacturing date, to ensure that the duration between manufacture and receipt is less than 6 months. Ideally, however, the manufacturing date and storage conditions should be provided by the manufacturer and/or retailer.

Even though it is not a typical grower practice to store BDMs for such a long period, it is important that BDM users understand the susceptibility of BDMs to aging, especially when BDMs are stored temporarily before field use 
or when unused mulch rolls from a given cropping season are saved for use in a future season. Environmental conditions during storage need to be considered as mulch storage can vary greatly from farm to farm. Mulchdependent properties (e.g., thickness, colorants, molecular composition, master batch type) influence the shelf life of BDMs and the impact of shelf life on BDMs' performance will differ between cropping systems, environments, and farming practices. All of these aspects need to be studied. Aging can have long-term impact on the mechanical performance of BDMs during crop production, and degradation of BDMs can impact specialty crop production.

\section{Literature cited}

Anunciado, M.B., D.G. Hayes, L.C. Wadsworth, M.E. English, S.M. Schaeffer, H.Y. Sintim, and M. Flury. 2021. Impact of agricultural weathering on physicochemical properties of biodegradable plastic mulch films: Comparison of two diverse climates over four successive years. J. Polym. Environ. 29(1):1-16, https:// doi.org/10.1007/s10924-020-01853-1.

ASTM International. 2011. ASTM D5035: Standard test method for breaking force and elongation of textile fabrics (strip method). ASTM, West Conshohocken, PA.

Briassoulis, D. 2004. An overview on the mechanical behaviour of biodegradable agricultural films. J. Polym. Environ. 12(2):65-81, https://doi.org/10.1023/ B:JOOE.0000010052.86786.ef.

Briassoulis, D. and A. Giannoulis. 2018. Evaluation of the functionality of bio-based plastic mulching films. Polym. Test. 67(1): 99-109, https://doi.org/10.1016/j.poly mertesting.2018.02.019.

Cowan, J.S., A.M. Saxton, H. Liu, K.K. Leonas, D. Inglis, and C.A. Miles. 2016. Visual assessments of biodegradable mulch deterioration are not indicative of changes in mechanical properties. HortScience 51 (3): 245-254, https://doi.org/10.21273/hortsci. 51.3.245.

Deroiné, M., A. Le Duigou, Y.M. Corre, P.Y. Le Gac, P. Davies, G. César, and S. Bruzaud. 2014. Seawater accelerated ageing of poly(3-hydroxybutyrateco-3-hydroxyvalerate). Polym. Degrad. Stabil. 105(1):237-247, https://doi. org/10.1016/j.polymdegradstab.2014. 04.026 .

DeVetter, L.W., H. Zhang, S. Ghimire, S. Watkinson, and C.A. Miles. 2017. Plastic biodegradable mulches reduce weeds and promote crop growth in day-neutral strawberry in western Washington. HortScience 52(12):1700-1706, https://doi. org/10.21273/hortscil2422-17.

Dharmalingam, S., D.G. Hayes, L.C. Wadsworth, and R.N. Dunlap. 2016. Analysis of the time course of degradation for fully biobased nonwoven agricultural mulches in compost-enriched soil. Text. Res. J. 86(13):1343-1355, https://doi. org/10.1177/0040517515612358.

DuBois Agroinovation. 2021. User manual for Bio360. 10 Sept. 2021. <https:// www.duboisag.com/>.

Emadian, S.M., T.T. Onay, and B. Demirel. 2017. Biodegradation of bioplastics in natural environments. Waste Manag. 59(1):526-536, https://doi. org/10.1016/j.wasman.2016.10.006.

Ghimire, S., E. Scheenstra, and C. Miles. 2020. Soil-biodegradable mulches for growth, yield, and quality of sweet corn in a Mediterranean-type climate. HortScience 55(3):317-325, https://doi. org/10.21273/hortscil4667-19.

Ghimire, S., A.L. Wszelaki, J.C. Moore, D.A. Inglis, and C. Miles. 2018. The use of biodegradable mulches in pie pumpkin crop production in two diverse climates. HortScience 53(3):288-294, https://doi. org/10.21273/hortscil2630-17.

Guerrini, S., C. Yan, M. Malinconico, and P. Mormile. 2019. Agronomical overview of mulch film systems, p. 241-264. In: T.J. Gutiérrez (ed.). Polymers for agri-food applications. Springer, Cham, Switzerland.

Harvey, J.A. 2005. Chemical and physical aging of plastics, p. 153-163. In: M. Kutz (ed.). Handbook of environmental degradation of materials. William Andrew Publ., Norwich, NY.

Hayes, D.G., M.B. Anunciado, J.M. DeBruyn, S. Bandopadhyay, S. Schaeffer, M. English, S. Ghimire, C. Miles, M. Flury, and H.Y. Sintim. 2019. Biodegradable plastic mulch films for sustainable specialty crop production, p. 183-213. In: T.J. Gutiérrez (ed.). Polymers for agri-food applications. Springer, Cham, Switzerland.

Hayes, D.G., L.C. Wadsworth, H.Y. Sintim, M. Flury, M. English, S. Schaeffer, and A.M. Saxton. 2017. Effect of diverse weathering conditions on the physicochemical properties of biodegradable plastic mulches. Polym. Test. 62(1):454-467, https://doi.org/ 10.1016/j.polymertesting.2017.07.027.

Kasirajan, S. and M. Ngouajio. 2012. Polyethylene and biodegradable mulches for agricultural applications: A review. Agron. Sustain. Dev. 32(2):501-529, https://doi. org/10.1007/s13593-011-0068-3.
Kijchavengkul, T. and R. Auras. 2008. Compostability of polymers. Polym. Int. 57(6):793-804, https://doi.org/10.1002/ pi. 2420 .

Krueger, M.C., H. Harms, and D. Schlosser. 2015. Prospects for microbiological solutions to environmental pollution with plastics. Appl. Microbiol. Biotechnol. 99(21):8857-8874, https:// doi.org/10.1007/s00253-015-6879-4.

Lalitha, M., V.K. Thilagam, N. Balakrishnan, and M. Mansour. 2010. Effect of plastic mulch on soil properties and crop growth-a review. Agr. Rev. (Karnal) 31(2):145-149.

Miles, C., L. DeVetter, S. Ghimire, and D.G. Hayes. 2017. Suitability of biodegradable plastic mulches for organic and sustainable agricultural production systems. HortScience 52(1):10-15, https:// doi.org/10.21273/hortscil 1249-16.

Ming, X. and H. Chen. 2020. Experiment on cultivation performance of plant fiberbased degradable film in paddy field. Appl. Sci. (Basel) 10(2):495, https://doi. org/10.3390/app10020495.

Moore, J.C. and A.L. Wszelaki. 2019. The use of biodegradable mulches in pepper production in the southeastern United States. HortScience 54(6):1031-1038, https:// doi.org/10.21273/hortscil3942-19.

Moreno, M.M., S. González-Mora, J. Villena, J.A. Campos, and C. Moreno. 2017. Deterioration pattern of six biodegradable, potentially low-environmental impact mulches in field conditions. J. Environ. Manage. 200(1): 490-501, https://doi.org/10.1016/j.jenv $\operatorname{man} .2017 .06 .007$.

Mosnáčková, K., M. Šlosár, J. Kollár, I. Janigová, A. Šišková, Š. Chmela, W. Sikorska, D. Perd'ochová, I. Gálisová, P. Alexy, I. Chodák, and J. Mosnáček. 2019. Ageing of plasticized poly(lactic acid)/poly(3-hydroxybutyrate)/carbon black mulching films during one season of sweet pepper production. Eur. Polym. J. 114(1):81-89, https://doi. org/10.1016/j.eurpolymj.2019.02.010.

Nogueira, D. and V.G. Martins. 2019. Use of different proteins to produce biodegradable films and blends. J. Polym. Environ. 27(9):2027-2039, https://doi. org/10.1007/s10924-019-01494-z.

Scarascia-Mugnozza, G., E. Schettini, G. Vox, M. Malinconico, B. Immirzi, and S. Pagliara. 2006. Mechanical properties decay and morphological behaviour of biodegradable films for agricultural mulching in real scale experiment. Polym. Degrad. Stabil. 91(11):2801-2808, https://doi.org/10. 1016/j.polymdegradstab.2006.02.017.

Serrano Ruiz, H., J. Eras, L. Martín-Closas, and A.M. Pelacho. 2020. Compounds released from unused biodegradable mulch materials after contact with water. Polym. Degrad. Stabil. 
178(1):109202, https://doi.org/10.1016/j. polymdegradstab.2020.109202.

Serrano-Ruiz, H., L. Martin-Closas, and A.M. Pelacho. 2021. Biodegradable plastic mulches: Impact on the agricultural biotic environment. Sci. Total Environ. 750(1):141228, https://doi. org/10.1016/j.scitotenv.2020.141228.

Sintim, H.Y., A.I. Bary, D.G. Hayes, M.E. English, S.M. Schaeffer, C.A. Miles, A. Zelenyuk, K. Suski, and M. Flury. 2019.
Release of micro- and nanoparticles from biodegradable plastic during in situ composting. Sci. Total Environ. 675(1): 686-693, https://doi.org/10.1016/j.scit otenv.2019.04.179.

Vroman, I. and L. Tighzert. 2009. Biodegradable polymers. Materials (Basel) 2(2):307, https://doi.org/10.3390/ma 2020307.

Yin, M., Y. Li, H. Fang, and P. Chen. 2019. Biodegradable mulching film with an optimum degradation rate improves soil environment and enhances maize growth. Agr. Water Manage. 216(1):127-137, https:// doi.org/10.1016/j.agwat.2019.02.004.

Zhang, H., C. Miles, S. Ghimire, C. Benedict, I. Zasada, and L. DeVetter. 2019. Polyethylene and biodegradable plastic mulches improve growth, yield, and weed management in floricane red raspberry. Scientia Hort. 250(1):371-379, https:// doi.org/10.1016/j.scienta.2019.02.067. 